\title{
Research on Chinese-Foreign Cooperative Program Majoring in International Business under the Belt and Road Initiative
}

\author{
Rangjia Cai ${ }^{1, a}$, Haiying $\mathrm{Ma}^{2, \mathrm{~b}^{*}}$ and Yongteng $\mathrm{Ma}^{3, \mathrm{c}}$ \\ 1,2,3 School of Economics, Northwest Minzu University, Lanzhou (730124), P.R.China \\ a522766108@qq.com, b Ixmahaiying8888@163.com, '1013130668@qq.com
}

Keywords: Chinese and foreign cooperative education; Talent training; the Belt and Road Initiative

\begin{abstract}
The Belt and Road Initiative is a new major development initiative identified by China. The Chinese-foreign cooperative education program for international business professionals will gradually shift from the original idea of focusing solely on cooperation between developed countries in Europe and the United States to the cooperation between the countries along the Belt and Road Initiative and cooperation between European and American developed countries. The idea of paying equal attention to running schools shows a trend of multi-dimensional and multi-level education. The implementation of the initiative has provided new demands, new challenges, new connotations, and opportunities for Chinese-foreign cooperative education. Chinese-foreign cooperative education should take the initiative in promoting connotation construction, opening up development paths, and standardizing system supervision, comprehensively deepen reforms, and promote Chinese-foreign cooperative education to multiple levels.
\end{abstract}

\section{Introduction}

The Silk Road Economic Belt and the 21st Century Maritime Silk Road Initiative are China's major new development strategies. Chinese-foreign cooperative programs are an important form of integration of China's higher education with international standards. It shows a trend of rapid development and forms an all-dimensional, multi-level, and wide-area development pattern. With the further advancement of The Belt and Road Initiative, how do universities collaborate with the needs of implementing The Belt and Road Initiative, and through the form of Chinese-foreign cooperative education in the international business sector, effectively link the resources of universities with the key resources of countries along The Belt and Road initiative.

Domestic and foreign scholars have carried out a large amount of research centering on Chinese-foreign cooperative programs. Chinese scholars' research on Chinese-foreign cooperative education can be divided into three stages. In the 1990s, some scholars in China began to pay attention to and study this issue. Among these, the theoretical research and practice of international business-professional cooperative education has become an important aspect of Chinese-foreign cooperative education in this period. Yang (2004) studies Chinese-foreign cooperative education from the micro level. Zhou (2005) proposes the introduction of foreign high-quality educational resources. Wang (2010) proposes a distinctive multiple financing models. Wang (2013) studied the issue of curriculum setting for cooperative education. Li (2014) proposed an improved initiative for the management of Chinese-foreign cooperative education. In the theoretical research on international business professional cooperative programs, Quan (2013) puts forward the idea of teaching orientation and course system innovation for international business accounting under Chinese-foreign cooperative education. $\mathrm{Lu}$ (2015) believes that in the context of globalization, the internationalization of education is the trend of education in the future, and the cultivation of international business talents should move from a technical and applied talent model to a combination of application and entrepreneurship. 


\section{The New Needs of Talents for Chinese-Foreign Cooperative Programs for International Business}

Talent is an important factor in the success of each specific project of The Belt and Road initiative. It is also related to the success or failure of The Belt and Road. As The Belt and Road initiative advances further, it will be able to become acquainted with the language and customs culture of countries along the Belt and Road Initiative, and international talents who are proficient in business and project engineering business knowledge will become increasingly scarce.

Demand for Engineering, Technology, and Management Talents of the Belt and Road Project will increase. With the opening and operation of the Asian Infrastructure Investment Bank, investments will be made in infrastructure, energy and transportation in countries along the Belt and Road, and a number of international major projects will be born. These projects have great demand for engineering project design, engineering technology research and development, and project management talents. According to statistics, during the 13th Five-Year Plan period, countries along the Belt and Road will need to invest nearly US\$100,000 for project construction and involve nearly a thousand international projects.

The Implementation of the Belt and Road Initiative will require a large number of international trade talents. The Belt and Road includes 65 countries, covering Southeast Asia, Central Asia, and Central and Eastern Europe. It is the world's longest-spanning economic corridor and the world's most promising economic cooperation zone. In terms of exports, mechanical and electrical products exported to 64 countries along The Belt and Road accounted for $21.75 \%$ of its total exports, and textiles and raw materials accounted for $33.9 \%$ of its total exports. Vietnam and Malaysia are important countries for the export of base metals and products in China. On the import side, China imported $50.43 \%$ of the total imports of minerals from 64 countries along the "Belt and Road", imported electromechanical products accounted for $16.15 \%$ of its total imports, imported transportation equipment accounted for $4.64 \%$ of its total imports, optical, clocks, and watches. Medical equipment accounts for $5.97 \%$ of its total imports.

Implementation of the Belt and Road Initiative will require a large number of Asian language talents. The shortage of foreign language talents in countries with The Belt and Road has become the bottleneck of The Belt and Road Initiative. There are more than 40 official languages in the 5 regions in Central Asia, Southeast Asia, South Asia, West Asia, and East Africa covered by the countries along the Belt and Road. However, the number of languages for college foreign language majors recruited in 2010-2013 in China only covers 20 of them. In the cultivation of foreign language talents, China has invested a great deal of manpower, material resources, and financial resources into English language training and has also achieved great results. However, there is insufficient attention and insufficient investment in the training of foreign language talents in countries along the Belt and Road. The problem is that our foreign language talents have not done enough in terms of diversity and multi-levels.

\section{The new Trend of Chinese-foreign Cooperative Programs under The Belt and Road Initiative}

Under the new background of the implementation of the Belt and Road Initiative, Chinese-foreign cooperative education for international business professionals will gradually shift from the original idea of focusing solely on cooperation between developed countries in Europe and the United States to the idea of paying equal attention to the cooperation between the countries along the Belt and Road and the cooperation between the developed countries in Europe and the United States, and pay more attention to it. Countries along the Belt and Road countries cooperate in running a school. Therefore, China's Chinese-foreign cooperative education will show a trend of diversified and multi-level education. As an important content of the implementation of the Belt and Road Initiative, international business will become an important part of Chinese-foreign cooperative education.

Development Trend of China's Education Internationalization. The Belt and Road Initiative is not only a new idea for international development, but also a major initiative for promoting China's domestic economic and social development. It is a major measure for China's comprehensive deepening of reforms. At present, China is advancing comprehensive and deepening reforms. The field of 
education is a key area for deepening reforms. From the perspective of the Belt and Road Initiative, reforms in the field of education must promote the internationalization of education in China. Promoting the internationalization of education is not only the overall requirement for the transformation of China's education development model, but also the individual requirements for the types and specifications of talents in different regions.

The Pace of Chinese-foreign Cooperative Programs. The transformation and development of China's education will open up a new era with the advancement of The Belt and Road occupation, and will also promote pragmatic cooperation in education, science and technology, and culture between China and countries along the route. Chinese-foreign cooperative programs are an important part of The Belt and Road Initiative. Education is an important route for the dissemination of civilizations. It can be said that countries along the Belt and Road countries are a new model of opening up to the outside world with Chinese-foreign cooperative programs. Chinese-foreign cooperative education has also fostered exchanges, cooperation and friendship with countries along the country while cultivating talents for countries along the route. At present, China has proposed expanding the scale of international students. Each year, it provides 10,000 government scholarships to countries along the route, and strengthens cooperation in science and technology through joint construction of joint laboratories, technology transfer centers, and maritime cooperation centers, through youth employment, entrepreneurship training, Cooperation in professional skills.

The Openness of Cooperative Education. Reform and opening up is a basic national policy of China. Promoting the opening up of China's education to the outside world is the proper meaning of the basic national policy of reform and opening up, as well as The Belt and Road Initiative. The improvement of educational soft power will become an important support for enhancing China's economic development level, expanding cultural influence, and ensuring national security. Chinese-foreign cooperative programs are an important way for the improvement of China's educational strength. It is also a very important way for China to speed up the level of internationalization of education, and naturally it has become an important force for the implementation of China's "Belt and Road" initiative. The implementation of the One Belt One Road Initiative will gradually increase the level of national development of education in China. The people in the countries along the route can improve their national quality by receiving better education, increase their national development capacity, and continuously improve their living standards and quality.

The Continuous Innovation Education Content. Chinese-foreign cooperative programs are a two-way interactive process. This model of schooling makes the roles of "bringing in" and going out alternate. In addition to cooperation in the field of teaching, Chinese-foreign cooperative education is a new trend in scientific research and an important part of Chinese-foreign cooperative programs. With the further advancement of The Belt and Road Initiative, the participation of educational resources, education systems, and education theories will become an important part of China-foreign cooperative education in the countries along the line. The contents and development forms of Chinese-foreign cooperative education will also be innovative in varying degrees, presenting rich content. For example, Xiamen University's branch office in Malawi is a groundbreaking attempt by China's Chinese-foreign cooperative education in countries along the Belt and Road and has very important practical significance.

China-Foreign Cooperation in International Business Professional. Running schools to blow up the development of international trade is the core and focus of the implementation of The Belt and Road Initiative. It is expected that the expansion of bilateral trade volume between countries will be the most directly visible result of The Belt and Road Initiative. With the in-depth implementation of the One Belt One Road Initiative, there will be a large number of scarce talents in the relevant fields of international business professionals, and talent will become the key to the effectiveness of the One Belt One Road One International Trade. Under the new situation, how to cultivate and bring up international business talents suited to the needs of The Belt and Road initiative has become an important issue that has been highly valued and in-depth studied in the education sector in China. It will also promote the development of Chinese-foreign cooperative education in international business schools in China. 


\section{New Connotations in the International Business Majors}

Chinese-foreign cooperative education, together with public universities and private colleges and universities, is also known as the Troika of higher education. It has played an active role in promoting the reform of China's higher education system and mechanism, broadening the channels for cultivating talents, and promoting education to the outside world. Under the background of the implementation of The Belt and Road Initiative, Chinese-foreign cooperative education, especially the development of Chinese-foreign cooperative education in international business, is facing new practices, new demands, and new trends.

Chinese-foreign Cooperative Education Provides a Scientific Basis. A very important mission of Chinese-foreign cooperative education is to strengthen related research with countries along the route, provide scientific decision-making basis for the implementation of The Belt and Road Initiative, and better policy communication between countries along the line. On the one hand, the Belt and Road initiative formulation has become increasingly scientific and democratic. It is necessary to carry out Chinese-foreign cooperative education with countries along the route, give full play to the scientific research advantages of Chinese universities, and provide scientific policy implementation plans and scientific decision-making basis. On the other hand, the dissemination of the "Belt and Road" policy needs to rely on the arrival of students from countries along the route. The dissemination of policies needs to rely heavily on the new mode of running schools, which is Chinese-foreign cooperative education. The realization of the function and purpose of the Belt and Road Chinese-foreign cooperative education needs to have a carrier for realization. The international business professional that serves the international trade along the Belt and Road has naturally become an important bearer of this mission.

Chinese-Foreign Cooperative Programs Provides Standards for Corporate Engineering. During the implementation of The Belt and Road Initiative, related construction projects mainly cover railways, pipelines, electricity, roads, ports and communications, and Asian Investment Bank will also strengthen related investment in these areas. The quality of construction projects is of concern to the world. Investment is inseparable from international business activities. The success of these projects depends largely on international business activities. In the implementation of the Belt and Road Initiative, China needs to establish a set of high-quality engineering quality standards. Enterprise engineering quality standards require China to give full play to the advantages of Chinese-foreign cooperative programs. In particular, fully understanding the actual needs of foreign projects for projects can fully leverage on the project advantages of Chinese-foreign cooperative education.

Formulating Rules for Trade and Finance. In the implementation of The Belt and Road Initiative, trade is a very important part of it. What kind of trade initiative and rules of the game are formulated by countries along the Belt and Road, and China should give full play to the role of the leading country in this regard. Chinese-foreign cooperative programs should do something in this regard. In particular, we must carry out some forward-looking research on these issues, conduct in-depth thinking on related issues, and timely summarize and provide feedback on related practice and exploration. This is a national trade and financial rule along the Belt and Road.

Participating in the Belt and Road initiative. The Belt and Road Initiative is an international grand initiative and a major policy with international vision and ambition that China has led to formulate and implement. In the implementation of such a initiative, it is necessary for all countries along the route to have a unified understanding of the Belt and Road strategic policy. Therefore, it is necessary to strengthen policy advocacy in this area. The international business activities of countries along the Belt and Road must naturally undertake this historic mission.

\section{Conclusions}

In the process of deepening the internationalization of China's higher education, especially the implementation of The Belt and Road Initiative, the status of Chinese-foreign cooperative programs for international business professionals has become increasingly prominent. To strengthen cooperation with 
countries along the Belt and Road Initiative, Chinese-foreign cooperative education for international business professionals will focus on increasing the introduction of foreign high-quality educational resources. In the process of developing Chinese-foreign cooperative education for international business professionals in China, the key and difficult point is to solve these personality problems. The breakthrough point for solving these problems is to conduct targeted curriculum setting. The curriculum construction is the basis of Chinese-foreign cooperative education, and it is the fundamental guarantee for the quality of Chinese-foreign cooperative education. In the process of Chinese-foreign cooperative education in the international business professional, it is very important to strengthen the study of small language courses, but it is also not necessary to go all the way, but it should be focused on small language courses.

\section{Acknowledgements}

This work was supported by the Pilot joint program of comprehensive professional reform of International Economics and Trade (Joint Program, USU and NWUN) (Grant No:2017XJZYZHGGSD-01) and by the Modernization and Social Harmonious Development in Ethnic Regions: Research and Innovation Team of Northwest Minzu University (Grant No: 31920180101)

\section{References}

[1] Jiao Guozheng, Review and Reflection on Chinese-foreign Cooperative Education in Colleges and Universities, Chinese Higher Education, 10 (2001) 42-48.

[2]Lin Jinhui, Research on the introduction of quality education resources in Chinese-foreign cooperative education, Educational Research, 10 (2012)34-41.

[3] Wang Wei, Analysis of Industrial Economics in Chinese-foreign Cooperative Education in Higher Education, Higher Education Exploration, 1 (2015)26-29.

[4] Sun Zhihui, Research on the matching initiative of Chinese-foreign co-operative education personnel training model, Heilongjiang Higher Education Research, 2 (2015) 145-147.

[5] Liu Tianbo, Teaching Reform and Practice of Chinese-Foreign Cooperative Education, Education and Teaching Forum, 2 (2015):87-92.

[6] Guo Qiang, Chinese-Foreign Cooperative programs: An Effective Path to the Transformation and Development of Local Universities, Education Review, 4 (2015)9-15.

[7] Zhang Jing, Discussion on the Innovation of Talent Cultivation in Chinese-foreign Cooperative programs, Journal of Zhengzhou Institute of Aeronautical Industry Management, 2 (2015) 131-135.

[8] Wu Lili, Discussion on the Teaching Mode of Chinese-Foreign Cooperative programs, Journal of High Education, 2(2015)1-8. 